\title{
SAUSAGE AND NUGGET PROCESSING TRAINING AT TUNAS BAJA ORPHANAGE, CILEGON, BANTEN
}

\author{
Rani ANGGRAENI ${ }^{* *}$ and Wiwit AMRINOLA ${ }^{2}$
}

${ }^{1}$ Food Technology Department, Faculty of Food Technology and Health, Sahid University, Jakarta, Indonesia ${ }^{2}$ Food Technology Department, Faculty of Engineering, Bina Nusantara University, Jakarta, Indonesia *rani.anggraeni34@gmail.com

\begin{abstract}
Children's Orphanage is a Social Welfare institution that has a responsibility to provide Social Welfare services for children who do not have guardians capable of caring for them live to obtain a comprehensive, appropriate, and adequate opportunity for development. Most orphanages in Indonesia are lack motivation and the absence of support for the children to conduct further studies. And also the absence of entrepreneur skills for life after graduating from the orphanage. Therefore, providing skills to foster children is needed. This PKM activity aims to provide solutions to encourage children in orphanages in the form of training in processing sausage and nugget food products, including skills in food processing following the guidelines of Good Practices, food processing technology, and packaging technology. This PKM activity has three stages: the preparation stage, the training stage, and the evaluation stage. The preparation stage is coordination between the team and partners. At the training stage, the section explains the technical guidance on food product processing and discussion. The results show that the sausage and nuggets processing skills of the orphanage children are increase. They can make sausage and nuggets on their own.
\end{abstract}

Keywords: sausage, nugget, orphanage, food processing, training, orphanage

\section{BACKGROUND}

Children's Orphanage is a Social Welfare institution that has a responsibility to provide Social Welfare services for children who do not have guardians capable of caring for them live to obtain a comprehensive, appropriate, and adequate opportunity for development (Kepmensos No. 50). Every child is entitled to welfare, care, and guidance based on compassion both in his family and in special care for natural growth (UU RI No. 4 Tahun 1979)

Most orphanages in Indonesia lack motivation, the absence of support for the children to conduct further studies, and also the absence of entrepreneur skills for life after graduating from the orphanage. Therefore, providing skills to foster children is needed. Children who turn 18 years old have to leave the orphanages and need to have financial solitude.

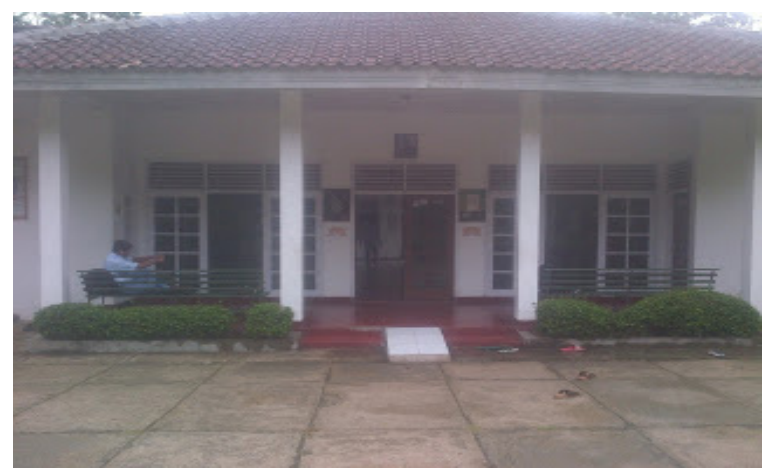

Figure 1. Front view of Tunas Baja Orphanage

The partner who cooperates in the community partnership program is Tunas Baja Orphanage. Tunas Baja Orphanage is an orphanage located at Jalan Kubang Lampung No. 12, Kotabumi Purwakarta, Cilegon, Banten. Tunas Baja Orphanage was established on December 21, 1987, and inaugurated by the President Director of PT. Krakatau Steel.
Children in orphanages are pre-teen and adolescent children with 13 boys and two girls. Some of them had to prepare to finish their education which was almost over. Therefore they need to increase their knowledge and skills as supplies after completing education.

The identification shows that there are problems faced by the partner and have to be solved. The issues are limited entrepreneurial skills, no business goals, and no expertise. One of the efforts to solve the problem is by fostering entrepreneurial skills among the youth of Tunas Baja orphanage in the form of training in meat-based food processing skills, such as sausages and nuggets. Because we see this business has a pretty good prospect, many consumers, and relatively easy to make. We expected that the training could be soft skills for the children in the orphanage and become a motivation for entrepreneurship, and they will become more financially independent.

Based on the description above, it is necessary to conduct training on how to grow entrepreneurial skills through meat-based food processing to teenagers in tunas Baja orphanage, Cilegon, Banten. This activity aims to provide training on developing entrepreneurial skills through meat-based food processing towards Tunas Baja to have entrepreneurial skills to live life independently and foster creativity and innovation in terms of entrepreneurship.

\section{METHODS}

Community Program is doing at Tunas Baja Orphanage, Cilegon, Banten by means lecturer and training. The Participants of this activity are orphanage children who are teenagers. This activity of this PKM is includes training, discussion, and Q\&A.

The community program is carried out in three stages: preparation, training, and monitoring evaluation. 
In the preparation step, the team conducts surveys and observations of the target orphanage. The second is the training stage that provides Good Practices, meat processing technology, and Packaging Technology. During the training process, participants were allowed to ask at the same time. The team also provided experience on how to start a business and hone creativity and innovation in managing the business.

Monitoring is doing while the activity is in progress to ensure the learning process and achievements. When an error occurs is immediately corrected to run according to the plan and target. Evaluation of output is doing by looking at the outcome of the activities listed in the Performance Indicators. If the evaluation results show that the desired externality has been achieving, the trainees can then run a business based on their skills.

The tools used in chicken nuggets processing are blenders, baking sheets, steamer, knives, cutting boards, basins, stoves, stuffers, mattress straps, and sausage casings. While the ingredients used are chicken, tapioca flour, eggs, mayonnaise, panir flour, onions, garlic, pepper, salt, sugar, beef, medium protein wheat flour, tapioca flour, ISP flour/ soybean flour, STIP, cooking oil, ice water, bratwurst seasoning (fine seasoning: nutmeg 1sdt, pepper 1 tsp, ginger, coriander, granulated sugar, oregano, salt), chili red food coloring and sausage casing.

Chicken nuggets are made in 4 stages, namely grinding, mixing, steaming, printing and frying. Chicken meat is first ground with a blender or food processor. Next, the ground chicken is mixed with eggs, tapioca flour, mayonnaise, salt, sugar, and fine seasoning, then stirred until evenly mixed. After mixing, the dough is put into a baking sheet container that has been coated with cooking oil so that it does not stick and then steamed for approximately 30 minutes. Next, the dough is removed from the baking sheet, then cut into pieces to taste. Then put into the egg beat and then toppled into the flour panir. Nuggets that have been produced can be directly fried or stored in the freezer and become frozen food.

Beef Sausage Making Procedure Beef That has been ground and then added salt and ice water. After mixing, the flour mix, eggs, fine seasoning, and red chili dye were mixed evenly. Furthermore, the dough that has been mixed evenly is inserted into a sausage stuffer or triangular plastic to put the dough into a sausage casing that has previously been soaked in water. The dough that has been put into the sausage casing is then tied to the desired size. Next, the sausage dough that has been in the case and tied up is then soaked in water at $70{ }^{\circ} \mathrm{C}$ for 30 minutes. After 30 minutes, the sausage can be removed and lined.

\section{RESULT AND DISCUSSION}

Based on the discussions with the Orphanage team, it decided to provide food processing training products that are pretty popular by the community, namely sausage and nuggets. Furthermore, the team prepares materials and tools. This PKM is doing in Tunas Baja Orphanage, Cilegon, Banten, attended by 15 foster children consisting of two young women and 13 young men. The fifteen foster children consisted of 2 high school students and 13 junior high school students.

Nowadays, people require more practical and efficient in living their lives. One of the consequences is the change in food consumption patterns. Changes in consumption style make ready to cook and ready to eat become the choice of people. Fast food consumption became a habit in the community because these foods are easy to obtain and can quickly serve (instant) (Suwoyo \& Heru 2006). One of the fast-food products that are pretty popular among the public is nuggets and sausages.

Nuggets and sausages are fast food products that are in high demand and well known by the public. Nuggets or sausages are food products that are practical and fast in the process of processing. Nugget products on the market are usually chicken nuggets, beef nuggets, and fish nuggets. Currently, chicken nuggets are one of the top-rated poultry products (Fatimah 2006). Meanwhile, meat sausages define as foods obtained from a mixture of fine meats containing no less than $75 \%$ meat with flour or starch with or without seasonings or other food additives permitted and incorporated into the sausage sheath (SNI 01-3820-1995). In addition, sausages define as food made from ground meat and seasoned and wrapped in a casing so that it is symmetrical cylinder-shape

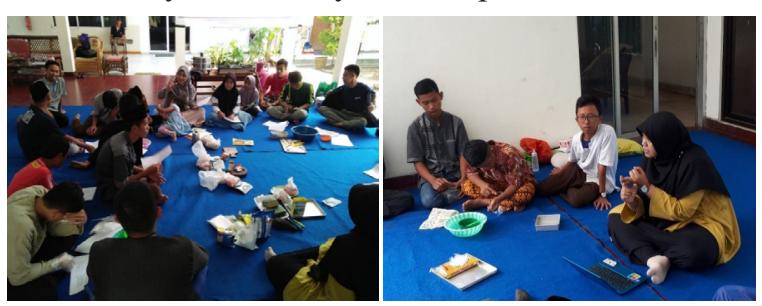

Figure 2. Provision of Materials on How to Process Good Manufacturing Practices (GMP)

Before training food processing nugget and sausage, the team explains about Good Manufacturing Practices (GMP). GMP is one of the critical factors to meet the quality standards or requirements set for GMP food; it is beneficial for the survival of the food industry, both small, medium, and large-scale. Through this GMP, the food industry can produce quality food, feasible consumption, and health safety. Good Manufacturing Practices (GMP) explains the requirements for handling foodstuffs in all food production chains, from raw materials to final products.

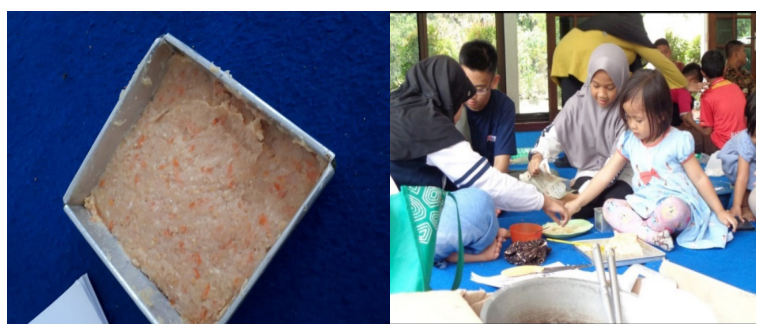

Figure 4. Nugget processing 
At the training, the children are divide into two groups, one group makes sausages, and the other groups make nuggets. Then after the break continued with the group who previously made sausages will make nuggets and vice versa. The sausage to be made is a meat sausage, while the nugget made is chicken nuggets. The process of making nuggets follows the method used by Laksono (2012). There are five stages in the nuggets production: milling and mixing seasonings, adding ice to keep the dough cold, steaming and cutting, coating with egg and breadcrumbs, pre-frying, and freezing.

The sausage-making process generally consists of nine stages: meal milling, mixing, insertion into a casing, binding, suspension, cooking, cooling, stripping, and packaging. The sausage casing consists of two types of edible casing that do not need to peel and a nonedible case that must remove before eating. The training process used nonedible casing. During the training process, the trainees are very active and enthusiastic in processing nuggets and sausages. They also actively ask questions about things that they do not understand

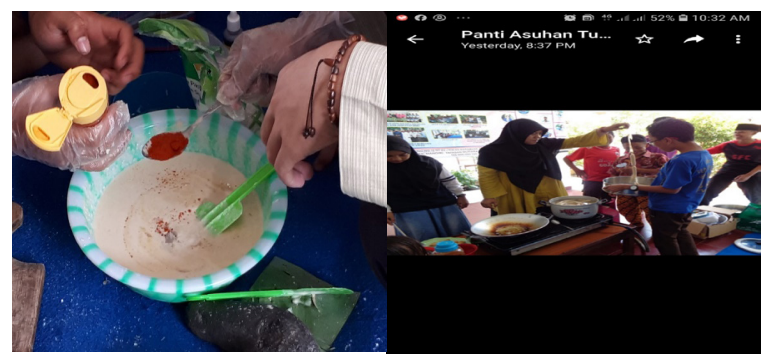

Figure 3. Sausage making process

All of the participants of this training look enthusiastic about following every step of nugget processing training. They listen to the explanation from the trainers and do their own every stage of processing. They will ask the trainer if they find something they did not understand.

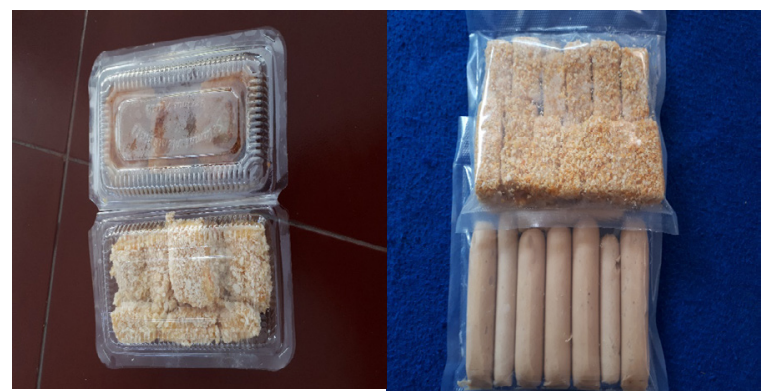

Figure 5. Sausages and nuggets in various packages

In addition to the production process, packaging is also an essential part of food products. Packaging is critical for marketing food products. Packaging is a creative design that associates shapes, structures, materials, colors, imagery, typography, and design elements with product information to distribute products to the market. Packaging is used to wrap, protect, ship, remove, store, identify and differentiate products on the market (Klimchuk and Krasovec, 2006). The main function of packaging is to maintain the product. However, now packaging is becoming a fairly important marketing tool (Rangkuti, 2010).
Based on the content structure, the packaging is divided into three types, namely: Primary Packaging, which is a packaging material directly accommodates food (milk cans, beverage bottles, etc.), Secondary Packaging, which is a packaging whose main function is to protect other packaging groups, such as cardboard boxes for milk can use containers, wooden boxes for wrapped fruit containers and so on and Tertiary and Quaternary Packaging, packaging required for storing, shipping or identification. Tertiary packaging is commonly used as a protector during transport. This activity also gives information about the types and how to choose the best packaging. So It isn't only attractive in terms of visuals and safe but also effective in protecting food products and listing informative labeling for consumers.

The evaluation results obtained are following the indicator. The evaluation data obtained include: (1) the number of participants who attended as many as 15 people so that the attendance rate reached $100 \%$, (2) the trainees seemed very enthusiastic during the activity until the training are complete, (3) Each participant are pretty active in the discussions at the time of making sausages and nuggets. (4) the expected outcome is that the participants have the skill to produce sausages and nuggets products. The PKM activity has been well. The participants and caregivers of orphanages hope that this activity continues to be sustainable in the future with a variety and innovative products

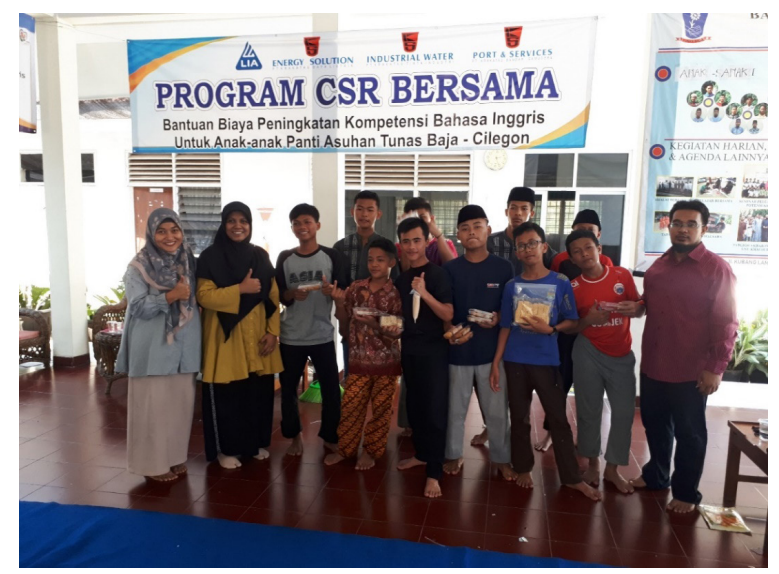

Figure 6. Presenters and trainees

\section{CONCLUSION}

Community Service Activities (PKM) entitled Sausages and Nuggets Processing Training for Children in Tunas Baja Orphanage, Cilegon, Banten has been well implementing. This activity received high enthusiasm from participants. It shows that the 15 participants are listened carefully and actively from the beginning to the end of the action. It concluded that all participants were able to practice the results of the training by being able to make their sausages and nuggets.

\section{ACKNOWLEDGEMENT}

This Community Service Activity is fully funded by The Community Service Grant of Sahid University Jakarta Batch IX in 2020 


\section{REFERENCES}

Decree of the Minister of Social Affairs No. 50/HUK/2004 concerning the Standardization of Social Home

Law of the Republic of Indonesia Number 4 of 1979 concerning The Welfare of Children

Djaali. 2000. Educational Psychology. Jakarta: UNJ

Suwoyo, Heru. 2006. Development of Chicken Nugget Vegetable Meat-Based SBB (Skinless Boneless Breast) with Carrot Flakes in PT. Charoen Pokphand Indonesia Chicken Processing Plant, CikandeSerang. Thesis: Bogor Agricultural University.

Fatimah, A. 2006. Addition of Carrot Flour and Agar to Increase Food Absorption Levels in Tilapia Nuggets. Faculty of Agriculture. Bogor Agricultural University.
Klimchuk, Marianne dan Sandra A. Krasovec. 2006. Design Packaging. Jakarta: Erlangga.

Kramlich WE. 1971. Sausage Product. In: Price JF and Schweigert BS (Eds.). The Science of Meat and Meat Product. 2nd ed. San Francisco: Freeman WH an Co.

Laksono, et al. 2012. Water Binding, Moisture Content, and Protein Chicken Nuggets substituted with White Oyster Mushrooms. Animal Agriculture Journal Vol. 1 No. 1. P685-696

Rangkuti, Freddy. 2005. SWOT Analysis: Business Case Dissecting Techniques. Jakarta: Gramedia 